British Journal of Ophthalmology, 1985, 69, 317-319

\title{
The eye and the seatbelt in Wessex
}

\author{
N F HALL,' A M DENNING,' A R ELKINGTON,' AND P J COOPER 2 \\ From the Departments of 'Surgery and ${ }^{2}$ Social Statistics, University of Southampton, Southampton SO9 5 NH
}

SUMMARY The records of all 373 patients undergoing surgery for perforation of an eye at the 10 eye units in the Wessex Regional Health authority (except the Isle of Wight) during February 1980 to January 1984 were examined. There were 86 admissions as a result of road traffic accidents (RTAs), and 287 admissions arising from other accidents. The estimated annual incidence of perforating eye injuries as a result of RTAs has decreased by $73 \%$ following legislation for the compulsory wearing of seatbelts by drivers and front seat passengers. There is no evidence that this abrupt fall in the incidence of injury can be satisfactorily attributed to any other factor.

Every eye Surgeon practising in the United Kingdom will have seen patients whose eyes were damaged in road traffic accidents (RTAs). Canavan et al., reporting the results of a 10-year survey of eye injuries in Northern Ireland, found that nearly a third (30.2\%) of perforating eye injuries stemmed from such accidents. The victims are characteristically in their 20 s or $30 \mathrm{~s}$, and their eyes are usually damaged as their heads move downwards on to the jagged lower remnants of a shattered, toughened windscreen. ${ }^{2}$ This has lead Du Fourmentel and Mouly ${ }^{3}$ to use the graphic phrase 'the guillotine of the windscreen.' This mechanism explains why these patients so often have a horizontal band of facial lacerations, and it also explains perforation of both eyes. ${ }^{4}$

Despite the great advances in microsurgical repair of such eyes the visual outcome is frequently disappointing. Lavergne ${ }^{5}$ reports that in one series of 97 patients with perforated eyes $29 \%$ of eyes eventually lost all 'functional vision.' In Canavan and colleagues' study, ' the most frequent reason for an eye being excised was damage incurred in an RTA $(27 \cdot 8 \%$ of all enucleations).

Australia led the way in countering many types of RTA injuries by the introduction of seatbelt legislation in $1971 .{ }^{4}$ Over the succeeding years a marked reduction in injuries has been reported from many countries. ${ }^{6}$ Legislation relating to the compulsory wearing of seatbelts by both driver and front seat passenger came into force in the United Kingdom on 31 January 1983 and is due to be reviewed by Parliament early in 1986.

Correspondence to Mr A R Elkington, Southampton Eye Hospital, Wilton Avenue, Southampton SO9 4XW.
Blake ${ }^{7}$ has reported that many people working in eye departments have recently noted an apparent decrease in the number of patients with eyes perforated in RTAs. We set up this study to discover the extent of this suspected trend, for, as Mackay ${ }^{8}$ has pointed out, the final test of the effectiveness of the legislation is the change in the number of casualties.

Three major considerations influenced the choice of the population for the study. First, we chose to investigate perforating eye injuries rather than lesser ocular injuries because of their worse visual prognosis. ${ }^{9}$ Secondly, we aimed to identify all cases in the study period. Thirdly, we needed to choose a study period long enough for the pattern of cases over time to be clear but short enough for other factors influencing the incidence rate of injuries to remain fairly stable. The period used is three years before and one year after the introduction of legislationthat is, 1 February 1980 to 31 January 1984.

\section{Material and methods}

In each of the 10 eye units on the mainland of the Wessex Regional Health Authority (RHA) the theatre books were used to identify all cases of perforating eye injuries. In each case the patient's name, unit number, and date of operation were used to trace the corresponding medical records. These records enabled all the cases of perforating eye injuries to be identified and subsequently divided into those resulting from an RTA and those from other causes. For RTAs we recorded the date of the accident, the age and sex of the patient, and other medical information.

Additional data have been obtained or derived 
Table 1 Eye injury and related data for February 1980 to January 1984 inclusive

\begin{tabular}{|c|c|c|c|c|}
\hline \multirow{2}{*}{$\begin{array}{l}\text { Accident year } \\
\text { February-January }\end{array}$} & \multicolumn{2}{|c|}{ Cases with penetrating eye injury } & \multirow{2}{*}{$\begin{array}{l}\text { Population }(\mathrm{m}) \\
\text { of Wessex } R H A^{*} \\
\text { aged } 15 \text { and over }\end{array}$} & \multirow{2}{*}{$\begin{array}{l}\text { Index of } \\
\text { average } \\
\text { daily } \\
\text { vehicle flow } \\
G B(1977=100) \neq\end{array}$} \\
\hline & $R T A$ & Non-RTA & & \\
\hline $1980-1$ & 34 & 70 & $2 \cdot 20$ & 106 \\
\hline 1981-2 & 24 & 75 & $2 \cdot 22$ & 105 \\
\hline $1982-3$ & 21 & 70 & $2 \cdot 24$ & 112 \\
\hline $1983-4$ & 7 & 72 & $2 \cdot 26$ & 117 \\
\hline
\end{tabular}

*Statistical year book. Chapter A. Winchester: Wessex RHA, 1984.

†Hampshire Police authority data (available on request).

‡Department of Transport. Transport statistics, Great Britain. HMSO: 1972-82. 1983-4 figure estimated from Press Notice.

§Estimated from Table 2.20 Transport Statistics, Great Britain. HMSO: 1972-82; and data supplied by University of Birmingham Accident Research Unit.

|Department of Transport Press Notice 2 dated 12th January, 1984.

Government Statistical Service. Press Notice 2. Road casualties in third quarter of 1983. London: Department of Transport. 1984.

from published sources. These include population data for the Wessex RHA; the number of RTAs in Hampshire divided into those involving fatal and serious injury, slight injury, and vehicle damage only; the proportion of cars and light vans in Great Britain having laminated windscreens; and the proportion of all front seat occupants wearing seatbelts.

\section{Results}

Table 1 shows that perforating eye injuries in RTAs fell from an average of $26 \cdot 3$ per annum during February 1980 to January 1983 to seven in the year immediately following the introduction of seatbelt legislation. This was a fall of $73 \%$ in the estimated annual incidence rate. In contrast over the same peri-1s injuries not related to RTAs averaged 71.7 and 72 respectively. The proportion of perforating eye injuries caused by RTAs dropped significantly $\left(\chi^{2}=14.45, \mathrm{df}=3, \mathrm{p}<0.01\right)$. The adult population of the Wessex RHA and the index of vehicle flow on roads in Great Britain (an amalgam of the number of vehicles and distance travelled by each vehicle) increased slightly over the study period. The annual number of accidents involving fatal or serious injury in Hampshire (a county typical of the mainland Wessex region) decreased by some $11 \%$ from $1980-3$ to 1983-4. This contrasted with the sharp increase in the number of accidents with damage only to vehicles in 1983-4 and an increase during the latter half of the study period in the total number of accidents. The proportion of all cars and light vans with laminated windscreens increased steadily over the period. In contrast the proportion of front seat occupants wearing seatbelts rose gently prior to legislation, after which it increased very sharply.

\section{Discussion}

We decided that scrutiny of theatre registers was the best method of identifying cases of perforating eye injury because patients with such injuries are virtually always dealt with surgically. This involved examining the records of the 10 specialist eye units and those of the general theatres where patients were sometimes treated in an emergency.

We noted not only cases of repair of a perforation but also cases of an intraocular foreign body; the removal of sutures; enucleation and evisceration; and any instance where the entry in the register did not make clear what operation had been carried out. We listed 1201 entries in this way. We were unable to trace the notes for $39(3.2 \%)$ of cases. However, these omissions were spread equally over the four years in question and hence do not lead us to suspect that any bias has been introduced into our study.

This system of retrieval also gave us the number of non-RTA perforating eye injuries. Reference to column 3 of Table 1 shows that these numbers remained steady throughout the four years. With no known change in the factors causing non-RTA injuries this is the expected pattern, and it supports the hypothesis that data recording and retrieval have been consistent over the study period.

Column 2 of Table 1 shows an abrupt drop in eye perforations coinciding with the introduction of seatbelt legislation. This could be attributed either to a change in the population exposed to risk of accidents giving rise to these injuries or to a change in the nature and circumstances surrounding each accident or a combination of these changes.

The magnitude of the population exposed to the risk of an RTA leading to a perforating eye injury has remained relatively stable over time. The adult 


\begin{tabular}{|c|c|c|c|c|}
\hline \multicolumn{3}{|c|}{ RTAs in Hampshire $\dagger$ involving } & \multirow{2}{*}{$\begin{array}{l}\text { Estimated \% } \\
\text { cars and light } \\
\text { vans with } \\
\text { laminated } \\
\text { screens in } \\
\text { Great Britain§ }\end{array}$} & \multirow{2}{*}{$\begin{array}{l}\text { Estimated } \\
\% \text { of front } \\
\text { seat } \\
\text { occupants } \\
\text { wearing } \\
\text { belts\| }\end{array}$} \\
\hline $\begin{array}{l}\text { Fatal and } \\
\text { serious } \\
\text { injuries }\end{array}$ & $\begin{array}{l}\text { Slight } \\
\text { injuries }\end{array}$ & $\begin{array}{l}\text { Vehicle } \\
\text { damage } \\
\text { only }\end{array}$ & & \\
\hline 2481 & 4414 & 8860 & 25 & 30 \\
\hline 2483 & 4392 & 8692 & 29 & 30 \\
\hline 2468 & 4870 & 9346 & 34 & 40 \\
\hline 2207 & 4959 & 10153 & 41 & 94 \\
\hline
\end{tabular}

population (column 4) has grown by only an estimated 20000 in some $2 \cdot 2$ million each year. The index of vehicle flow on roads in Great Britain (column 5) has risen by about $10 \%$ over the period. In a similar way the annual number of RTAs in Hampshire (columns 6, 7, and 8) has increased by about $10 \%$. Thus the accident rate has remained relatively stable over the study period. We also note the significant change after the introduction of legislation in the distribution of accidents by the severity of the injuries sustained $\left(\chi^{2}=93.04, d f=6, p<0.01\right)$. Fatal and serious injuries (column 6) declined by $11 \%$, accidents involving damage to vehicle only (column 8 ) increased by $9 \%$, with a $2 \%$ increase in the number of accidents involving slight injuries (column 7). These patterns for Hampshire accord with those reported for Great Britain. ${ }^{10}$ The results support the hypothesis that it is a change in the nature and circumstances of the RTAs which has led to the sharp fall in fatal and serious injuries in general and perforating eye injuries in particular.

Mackay et al. " " have emphasised the importance of laminated rather than toughened windscreens in the prevention of eye injuries incurred in RTAs. During the study period an increasing number of newly registered cars and light vans were fitted with laminated windscreens (rising from an estimated $45 \%$ in 1980 to an estimated $90 \%$ in 1984). The result has been an accelerating increase in the proportion of all cars and light vans with laminated windscreens. However, this smooth increase is not in accord with the sharp fall in perforating injuries in RTAs between the third and fourth years of the study. It may in part explain the steady fall in injuries during the three years prior to seat-belt legislation. Over the period January 1980 to January 1983 there was a slight increase in the proportion of front seat occupants wearing seatbelts (an estimated 30 to $40 \%$ ). During the following year there was a dramatic rise to an estimated $94 \%$ wearing seatbelts.

We believe that there is only one explanation for the pattern observed, namely, that the compulsory wearing of seat belts is a direct cause of the dramatic reduction in the annual incidence of perforating eye injuries in road traffic accidents.

We thank D Moss, R D Finlay, J D Griffiths, D E Jones, M D P Crick, E D Dorrell, H J Frank D. Boase, R E Butler, P J Fenton, J C Tudor, D M Lobb, A J Ogg, M J Absolon, I H Chisholm, J I McGill, C B Walker, J Ramsey, J D Strong, R C Kempster, G J Romanes, and $\mathrm{J} \mathrm{C} \mathrm{McGrand} \mathrm{for} \mathrm{allowing} \mathrm{us} \mathrm{to} \mathrm{study} \mathrm{the} \mathrm{notes} \mathrm{of} \mathrm{patients} \mathrm{under}$ their care. We thank too, the chief constables and accident prevention officers of Hampshire, Wiltshire, Dorset, Avon, and Somerset for accident data in their regions; the departmental secretaries and records staff in the various centres for identifying case notes; and the theatre staff in the hospitals concerned for making theatre registers available for scrutiny. We are also indebted to S J Keightley, Miss J Olver, Dr J C Catford (Wessex RHA), C A Smith (Accident Research Unit, Birmingham University), Mrs P Robinson (Library Service) and Mrs S E Emery, who largely co-ordinated the study and typed the manuscript.

\section{References}

1 Canavan YN, O’Flaherty MJ, Archer DB, Elwood JH. A tenyear survey of eye injuries in Northern Ireland, 1967-76. Br J Ophthalmol 1980; 64: 618-25.

2 Keightley SJ. Serious eye injury from windscreen contact. $J R$ Soc Med 1983; 76: 911-6.

3 Du Fourmentel C, Mouly R. Les traumatismes de la face au cours des accidents de la route. Mem Acad Chir (Paris) 1969; 95: 558-63.

4 Trinca GW, Dooley BJ. The effects of mandatory seat belt wearing on the mortality and pattern of injury of car occupants involved in motor vehicle crashes in Victoria. Med J Aust 1975; i: 675-8.

5 Lavergne G, Dereume-de Corte MT. Les perforations oculaires par fragments de pare brisé. Rev Med Liege 1972; 27: 831-4.

6 Bernard-Andersen $\mathrm{K}$. Use and effects of seat-belts in 21 countries. Oslo: Transportokonornisk Institute, 1978.

7 Blake J. Road blindness. Br Med J 1983; 287: 626-7.

8 Mackay GM. Injuries from glass in motor vehicles. In: Proceedings of the second conference on motor vehicles and motor engineering. Sopron: 1971.

9 Soni KG. Eye injuries in road traffic accidents. Injury 1973; 5: 41-6.

10 Government Statistical Service. Road accidents and casualties in Great Britain: 3rd quarter 1983. London: Department of Transport, 1984

11 Mackay GM, Gloyns PF, Hayes HRM, et al. Some aspects of facial injuries in present day cars. In: Proceedings of the VIIIth international technical conference on experimental safety vehicles. Wolfsberg: 1980. 